Pakistan Journal of Social Sciences 7 (2): 76-80, 2010

ISSN: $1683-8831$

(C) Medwell Journals, 2010

\title{
Evaluation of Effectiveness of Marketing Communication Mix Elements in Nigerian Service Sector
}

\author{
${ }^{1}$ Olorunleke Kola and ${ }^{2}$ S.T. Akinyele \\ ${ }^{1}$ Department of Business Administration, Ondo State University, Akungba, Nigeria \\ ${ }^{2}$ Department of Business Studies, School of Business, Covenant University, Ota, Nigeria
}

\begin{abstract}
Creating effective communication with customers is the most important aspect in services marketing. To date we still have poor understanding of the role of effective marketing communication with customers in attracting and maintaining prospective and present customers. This research study assess the effectiveness of advertising and personal selling practices of Nigerian service sector in communicating with its customers with the aim of finding solutions to improve the existing communication and customer satisfaction. After reviewing related literature, a questionnaire was prepared and distributed to 200 customers, out of which $25 \%$ from the telecommunications and 15\% each from the remaining seven service industries viz banking and insurance, education, travel, tourism, hotel industry and hospital industry used to gather the data about the effectiveness of advertising and personal selling activities. The participants were selected randomly once the service type is determined by stratified sampling. The data collected was analyzed based on predetermined rating factors and expected results of performance with SPSS software package. In conclusion the findings of the analysis showed that Nigerian service sectors advertising and personal selling indicated moderately effective in providing information, creating awareness, changing attitude, ineffective in building company image and enforcing brand loyalty. The research also identified lack of integration between advertising and personal selling.
\end{abstract}

Key words: Personal sellin, advertising, communication, mix, customers, services marketing

\section{INTRODUCTION}

Organizations exist to attain certain mission for undefined period of time. In order to exist in the business for a long period of time, organizations must look for effective and efficient ways of doing business activities to achieve organizational objectives. At present due to environmental dynamism and competitiveness, the struggle for survival and succeeding in the business has become more difficult and challenging. The growth trend and nature of the service industry with the competitive environment brought several and special problems for services marketing. since service encounters are complex and multiple factors affect interactions, organizations have to adopt holistic marketing approach to deal with these problems. Holistic marketing approach for services requires external marketing which deals with the interaction of the organization of the company as a whole with the customer in terms of company product, price, distribution channels and promotion activities.

Internal marketing is the process of engaging the support and commitment of employees and other organizational members for the goals and objectives of the company (Lancaster and Reynolds, 2004) and interactive marketing deals with interaction of frontline employees with customers in terms of understanding and solving customer's problems attentively. One of the four P's of marketing mix is promotion also known as marketing communication. Organizations have to communicate with their existing customers about what they are doing. Marketing communication is very important and at the same time challenging in the service sector as the nature of services is characterized by intangibility of the service product, which is decisive to convince customers on the value of a product. The intangibility of services has a number of managerial implications.

Marketing communication can be defined as all strategies, tactics and activities involved in getting the desired marketing message to intended target markets, regardless of the media use. Most service marketers have access to numerous forms of communication, referred to collectively as the marketing communication mix. The mix includes advertising, personal contact, publicity and public relations, sales promotion, instructional materials and corporate design (Lovelock and Wirtz, 2004). Marketing communication mix

Corresponding Author: Olorunleke Kola, Department of Business Administration, Ondo State University, Akungba, Nigeria 
elements provide information and consultation that are important components to add value to a product or services. Customers need information about the features of the product or service, its price and how they can access it, to make informed purchase decision. Thus, if customers are able to get the necessary information about the product timely and adequately, they may feel that they are buying quality product or service. This means having good and effective communication channels adds value to the product or service of the company as customers have confidence on their purchase. Generally, taking into account the nature of the service industry, the challenges it brings to the organizations and the need to follow holistic marketing approach to effectively interact with customers highlights the importance and significance of marketing communication activities. In service setting, marketing communication tools are especially important because they help create powerful images and a sense of credibility, confidence and reassurance. Though it would be wise and important to evaluate the effectiveness of all the elements, the researchers assessed the effectiveness of only advertising and personal selling because of the intense usage of advertising and personal selling elements in the Nigerian service sector and also to reach different types of audience, investment requirement, audience coverage and efforts required.

Any investment has to bring some return for its investor. Evaluating the effectiveness of a particular investment helps organizations to realize whether their investment is worthy or not. Investment on advertising campaign and sales force takes major share of organizations investment for marketing activities in general and advertising and sales force in particular helps to identify drawbacks of existing marketing practices and make necessary corrective actions to improve marketing activities effectiveness and efficiency as the whole efforts of organizations fruitfulness lies on marketing at the end of the day.

Generally, advertising has the potential to inform the masses, present and prospective consumers about the goods and services of a company and force them to visit the company's manufacturing and or distribution centers for further information and making purchase decisions. Advertisements for services should provide symbols or tangible cues, as concrete signals of the service's abstract attributes (Lacobucci, 2001). Thus communicating and convincing customers to buy services products is by far more challenging than selling manufacturing products. Personal selling, in turn has the potential and opportunity to persuade those who can come to the company's office with background information about the service from company advertisement by responding to customer's questions and doubts about the service. Personal selling involves three basic sales tasks as order-getting, order-taking and supporting (Perreault and Mccarthy, 2002). In this regard, the researcher can articulate strongly, advertising brings the horse and personal selling helps to ride it to the desired destination. The interactive nature of personal selling also makes it the most successful promotional method for building relationship with customers. So personal selling is the most useful communication tool at certain stages of the buying process, particularly in building up buyers trust, choices, certainly and proceedings. This is most imperative especially for service companies particularly in developing and underdeveloped countries.

Evaluating of advertising and personal selling: As it is very important and decisive to evaluate the effectiveness of any business activity so does to evaluate the effectiveness of marketing communications elements. The main thing here is that how can we evaluate the effectiveness of marketing communication tools. Though there are many ways to measure the effectiveness advertising and personal selling, the researcher would like to concentrate on what these activities add to make Nigerian services sector's communication with its customer more effective.

In light with this the assessment of the effectiveness of Nigerian service sector's advertising and personal selling primarily and dominantly concentrated on the communication effects. Advertising involves making decisions on the five Ms-mission, message, media, money and measurement (Kotler, 2001).

Advertising programme can be measured in terms of both communication and sales effects. Measuring the communication effect can be done before or after the advertisement is printed or broadcast.

Measuring advertising after broadcast evaluates how the ad affected consumer recall or product awareness, knowledge and preferences. In the same manner, sales person's performance can also be measured by gathering information from different sources. These include sales report, personal observation, customer survey and talks with the other salespeople (Kotler and Armstrong, 2005). Both advertising and personal selling effectiveness can be measured in terms of communication and sales effects. Many companies measure the effectiveness of their advertising campaign in terms of its communication effects as how does the advertising create awareness, provide information, stimulate demand, enforce brand loyalty? In fact, there are companies that measure the effectiveness of their advertising in terms of its effect on company sales. However, most agree that 
measuring effectiveness of advertising in terms of sales effect is difficult as there are many things to affect buying decisions other than advertising. Likewise, effectiveness of personal selling activities most dominantly is measured in terms of sales effects. There are companies that measure effectiveness of their sales force and personal selling activities in terms of communication effect like how willing are the sales people to solve customer's problems? How competent are the sales people to provide adequate information about the product? And how are they approaching customer according to their individual needs?

Therefore, for the sake of simplicity and uniformity the researcher concentrated on measuring the effectiveness of Nigerian corporate sector advertising and personal selling in terms of their communication effects by gathering primary data from customers.

\section{MATERIALS AND METHODS}

The research was conducted to access the effectiveness of Nigerian service sector's advertising program and personal selling practices in terms of the five main objectives of marketing communication mix which include the ability to provide information, create awareness to change attitude to build company image and to enforce brand loyalty and finally the researcher attempted to find the synchronization between this two elements. The research undertook to evaluate the effectiveness of Nigerian service sector's advertising by collecting data from customers about sectors already broadcasted advertising. The collected data shows how advertising affects customers' behavior in terms of its objectives.

Similarly, the study also strived to evaluate the performance of Nigerian service sector's sales people by collecting data from customers. The data collected shows how willing are the sales people to solve and clear customer's problems and doubts, how capable are they to provide timely and relevant information.

Sampling framework: The sample frame for this study was only those customers who are currently using the services of Nigerian telecommunications, banking, insurance, travel, hotel, tourism, education and hospital in different areas of Nigeria capital, Abuja. The sample size was 500 customers in order to make the research manageable. The research participants were selected randomly once the total and specific number of customers from each service sector is determined by stratified sampling. Of the total 500 sample dimension, 150 were set to be from Nigerian telecommunications and 50 each from the remaining seven sectors viz-banking, insurance and travel, tourism, hotel, education and hospital industries.

Data collection: Accessing and collecting data was not an easy task as the researcher tried to collect the data from different people living in different areas of Abuja, the Nigerian capital. A questioner was used with questions that are relevant and helpful to extract the opinions of customers about their communication with Nigerian service sector. The questions enabled research participants to express their opinion on the effectiveness of service firms. Advertising and personal selling elements on selected five parameters and integration between advertising and personal selling activities. The method of data collection was convenience type. Questioners were given physically to only willing customers and collected within the shortest time possible.

Data analysis: Collected data was analyzed based on the consistent with research questions and objectives and the understanding and judgments of the researcher. The data was analyzed based on the type of questions designed and response provided. The responses provided to the rating (scale) questions was analyzed based on the scale allocated to the factors. The rating was numerical and it ranged from one to four in which the least number shows the effectiveness of the two marketing communication tools and the highest number shows the effectiveness and the middle two rating points shows the moderately effective in influencing consumer behavior. The analysis was made based on the following performance rating scale for each investigative question's response. If $>70 \%$ of the respondents agreed on the issue it can be said that the performance is effective if the percentage of respondents who agreed on the issue is between $50-70 \%$, it is said to be moderately effective and if the percentage of respondents who agreed on the issue is below $50 \%$. It is said to be ineffective. The researcher used Statistical Package for Social Sciences (SPSS) to analyze responses for rating questions.

\section{RESULTS AND DISCUSSION}

\author{
Advertising \\ Providing information: Out of 500 respondents $340(68 \%)$ \\ said the Nigerian service sector's advertising was \\ moderately effective in providing information about their \\ services. And $50(10 \%)$ and $110(22 \%)$ respondents \\ expressed effective and ineffective opinion, respectively. \\ This means Nigerian services sector's advertising was \\ providing sufficient information for customers about its \\ services and as a result, customers are able to make
}


informed decisions about the product or services features, quality, prices, utility, availability, convenience and the like consumers find it easy to decide with such ready information to take a final purchase decision. Nigerian service sector advertising acts as a driving force in taking purchase decision to its markets.

Creating awareness: Out of the total respondents, $345(69 \%)$ believed that advertising was moderately effective in creating awareness about the services offered by the company. And $60(12 \%)$ and $95(19 \%)$ responded to advertising given by the service sector was effective and ineffective in that order. From this data of 405 (81\%), we can generalize that Nigerian service sector's advertising is capable of increasing customers awareness about its service. This means customers are aware of what Nigerian sector is doing as a result of the information they got from advertisements and this is also more valuable for the service sector to attract new customers as well to retain the existing customers.

Changing attitudes: From the total respondents $40(8 \%)$ and $335(67 \%)$ uttered that advertisements of service sector in Nigeria was changing attitudes effectively and moderately effective. And the remaining $125(25 \%)$ conveyed their dissatisfaction on advertisements of service sector in changing their attitudes. This implies that Nigerian service sector's advertisement has moderate potential to convince people and change their attitude towards services of respective service firms. Nigerian service sector's advertising is providing maximum information about product/service required by the consumer which is more constructive to change the attitude of the market.

Building company Image: Only 25(5\%) and 45(9\%) expressed advertisements were effective and moderately effective, respectively in building company image. Significant percentage of respondents $(86 \%)$ said that advertisements were totally ineffective in building company's image.

This indicates advertisements of Nigerian service sector mostly failed in building company image. This indicates advertisement of Nigerian service sector mostly failed in building company's image among customers. Frankly speaking, Nigerian advertising industry not properly developed both professionally as well in preparing creative advertisement. Consequently, either the advertising industry or service sector don't have proper idea in introducing the image building advertising or the advertisement which inflicts brand quality.
Enforcing brand loyalty: No $>30(6 \%)$ and $60(12 \%)$ said that advertisements were effective and moderately effective in enforcing brand loyalty among the customers. Majority of the respondents $410(82 \%)$ expressed advertisements were ineffective in enforcing brand loyalty. This connotes advertisements of this sector unsuccessful in enforcing brand loyalty.

\section{Personal selling}

Provide information: Out of the total responses, combined figure of $66 \%$ believed Nigerian sector's sales people provide adequate and relevant information effectively and moderately effective. This means sales force is showing moderate efforts to provide detailed and relevant information. Personal selling by its very nature is capable of providing more flexibility being adaptable. In this case also Nigerian service sector's front line sales force can adjust them to the varying needs, moods, motives, impulses, attitudes and other behavioral variables of the consumers with a view to communicate maximum information about their services (Table 1).

Creating awareness: From the total respondents, only $51 \%$ assured that salespeople of Nigerian service sector were moderately effective in creating awareness about the services they offered and $44 \%$ expressed sales people were too mechanical and lethargic at the time of service encounter which is more crucial in service sectors. The efforts put in the salesperson are highly focused on a single customer or a small group of customers has the chance to provide information or to create awareness about their services without distortion and diffusion. As a result of one to one and one to small group of presentations, Nigerian service sector frontline sales teams are trying to create maximum awareness about economic, functional utility and other auxiliary benefits associated with their services to the customers.

Changing attitudes: Only $42 \%$ said sales force was not trying to change attitudes and they were ineffective at the time of interaction, while $56 \%$ believed that sales people were moderately effective. This denotes that service sector's sales people have moderate potential to convince customers and change their initial attitude towards their service. The salespeople are in effect, researchers. Being in direct contact with the customers, they have the advantage of collecting and transmitting the relevant market information affecting his company. Such timely, authentic and verifiable data is the basis of vital decisions, strategies and tactical adjustments in maintaining positive attitude in the minds of the customers. 
Pak.J. Soc. Sci., 7 (2): 76-80, 2010

Table 1: Customers overall evaluation of advertising and personal selling for Nigerian service sector

\begin{tabular}{|c|c|c|c|c|c|c|c|c|}
\hline \multirow[b]{2}{*}{ Variables } & \multicolumn{3}{|c|}{ Advertising } & \multirow[b]{2}{*}{ Total } & \multicolumn{3}{|c|}{ Personal selling } & \multirow[b]{2}{*}{ Total } \\
\hline & $E^{*}$ & $\mathrm{ME}^{* * *}$ & $\mathrm{IE}^{* * * * * *}$ & & $\mathrm{E}^{*}$ & $\mathrm{ME}^{* * *}$ & $\mathbb{E}^{* * * * *}$ & \\
\hline Provide information & 50 & 340 & 110 & 500 & 65 & 265 & 170 & 500 \\
\hline Create awareness & 60 & 345 & 95 & 500 & 25 & 255 & 220 & 500 \\
\hline Changing attitudes & 40 & 335 & 125 & 500 & 10 & 280 & 210 & 500 \\
\hline Building company image & 25 & 45 & 430 & 500 & 10 & 20 & 470 & 500 \\
\hline Enforcing brand loyalty & 30 & 60 & 410 & 500 & 20 & 65 & 415 & 500 \\
\hline $\begin{array}{l}\text { Integration between advertising } \\
\text { and personal selling }\end{array}$ & 66 & - & - & - & - & - & 434 & 500 \\
\hline
\end{tabular}

$\mathrm{E}^{* *}$ : Effective; $\mathrm{ME}^{* * *}$ : Moderately Effectives; I $\mathrm{E}^{* * * * *}$ : ineffective

Building company image: Majority of the respondents (94\%) expressed sales people never tried to increase their company image. Only $6 \%$ of the respondents said that occasionally, sales people were saying about their company to build its image. This means service sector's sales people are totally ineffective in building company image among the customers. Nigerian service sector's frontline sales teams are slowly learning in creating long lasting impression among their clientele in building company image by clearly explaining the entire required information about their services as well as other socially responsible activities taken up their company.

Enforcing brand loyalty: In this case $83 \%$ of the respondents whispered that service sector sales teams were totally ineffective in enforcing brand loyalty. Only $13 \%$ said personal selling teams were moderately effective which means these are not successful in developing brand loyalty among the customers. Even though customers were not happy with the abilities of Nigerian frontline sales force particularly on building company image and enforcing brand loyalty, they are trying a lot to pull the customer with a logical selling process starting with attention and ending with action. Further bring the consumer back to the track by repetitions and reinforcements. Finally, the researcher tried to discover the integration factor between advertising and personal selling elements of this sector. Approximately $86.8 \%$ of people alleged that there was a great mismatch between the information given by the sector's advertisements as well by the sales people. This means what is transmitted by the Nigerian service firms through their advertisements differ from the information provided by sales people about the same issue.

\section{CONCLUSION}

The entire research is assessing the effectiveness of marketing communication mix elements viz; advertising and personal selling of Nigerian service sector revealed that both these elements are moderately effective in providing information, creating awareness and changing attitude whereas ineffective in building company image and enforcing brand loyalty. Moreover, the analysis of data also disclosed that Nigerian service sector's advertising and personal selling are not performed in an integrated way to provide consistent and reliable information to its customers. The researcher clearly observed the major problem here is not from the employee's side, companies failed to provide proper training for their frontline sales teams in terms of human psychology and consumer buying behavior, knowledge about company's product/services, competitive environment, types of customers and their characteristics, communication skills and most importantly knowledge about the selling process.

\section{REFERENCES}

Kotler, P., 2001. Kotler on Marketing: How to Create, Win and Dominate Markets. Simeon and Schuster Ltd., London, pp: 108.

Kotler, P. and G. Armstrong, 2005. Principles of Marketing. 11th Edn., Prentice Hall, New Delhi, pp: 467-500.

Lacobucci, D., 2001. Service Marketing and Customer Service, Kellogg on Marketing. John Wiley and Sons Inc., New York, pp: 322.

Lancaster, G. and P. Reynolds, 2004. Marketing. Palgrave Macmillian, New York, pp: 411.

Lovelock, C. and J. Wirtz, 2004. Services Marketing People, Technology, Strategy. 5th Edn., Pearson Education International, New Jersey, pp: 125.

Perreault, D. and J. Mccarthy, 2002. Basic Marketing. 14th Edn., McGraw-Hill, New York. 